\title{
Preserving Water Culture: Local Festivals (Matsuri) in Japan and Sedekah Laut in Pantai Utara Jawa Jepara Indonesia
}

\author{
Sri Indrahti ${ }^{1-}$, and Fildza Andita Meirina ${ }^{2}$ \\ ${ }^{1}$ Department of History, Faculty of Humanities, Diponegoro University, Semarang - Indonesia \\ ${ }^{2}$ Department of History, Faculty of Humanities, Diponegoro University, Semarang - Indonesia
}

\begin{abstract}
Indonesian and Japanese cultures have similarities in maintaining sustainability in nature. In Japan, preserving nature can be done by the traditional ceremony (Matsuri) with water as one of the mediums. In Indonesia, there is a ceremony too called Sedekah Laut, which is carried out by groups of fishing communities in the cultural element as a system of livelihood. Although it has a different series, Matsuri in Japan and Sedekah Laut in Jepara are a form of gratitude to nature by preserving and maintaining the cleanliness of nature through culture. This research aims to portray human and nature relationships and how to preserve them through culture. The two traditions involving many people for preserving nature in harmony is not just one person's responsibility, but together. This research uses methods through comparisons of Indonesian and Japanese traditional ceremonies. This research also used data collection methods through primary sources by in-depth interview and secondary sources by books, publication journals, and online news. This research also provides benefits that traditional ceremonies cleanse nature from damage and the attitude of cooperation of the community that together maintain the sustainability of nature.
\end{abstract}




\section{Introduction}

Japan is an island country located off the east of Asia and bordering the Okhstosk sea to the north, the Pacific Ocean to the east, the East China Sea and Filipino sea to the south, and the Japan sea and Korean sea west. Unlike Indonesia has 2 (two) seasons (summer and rainy), Japan has 4 (four) seasons (spring, summer, autumn, and winter). Even though Japan is one of a country with exceptionally high rainfall. Moreover, Japan is surrounded by mountains with is short rivers. The government makes an effort to build the dam to accommodate rainwater, irrigate the farm, prevent flood, recreation, etc. [1]. Water becomes part of human life, not only for economic, water is helpful for Japanese cultures. Culture is the quality of a person or society. Culture consists of everything that is produced, stands, and shares symbolic experiences [2]. In Japan, water is used for Japanese festivals. The festivals were lively, and the public could see the procession. One of the biggest festivals is Tenjin Matsuri. Tenjin is sky gods, and matsuri is festival. The ceremony was held in July using water in the process. The purpose is interpreted as ceremony and purifying ourselves, dedication for kami (gods), praying, a form of gratitude. In Indonesia, there is also a ceremony that uses water for the procession. In Jepara, there has ceremony called Sedekah Laut. Tenjin Matsuri and Sedekah Laut have the same interpretation: gratitude for the blessings obtained, prayer for the blessings, and safety in living life. Sedekah Laut is the existence of an Islam with HinduBuddha ritual culture.

\section{Traditional Ceremony of Sedekah Laut and Tenjin Matsuri}

\subsection{Procession, Meaning, and Sedekah Laut Jepara Ceremony Continuity}

Sedekah Laut Jepara Ceremony in Ujung Batu villages lasts for 2 (two) days, on $6^{\text {th }}$ and $7^{\text {th }}$ Shawwal. The $6^{\text {th }}$ is the preparations, and then the $7^{\text {th }}$ Shawwal is followed by the ceremony climax. There also sequences, starting with buffalo slaughtered, Selamatan and pilgrimage (ziarah), wayang kulit in TPI Ujung Batu performance, pelarungan ceremony and ends with Lomban.

The buffalo to be butchered through a procession of the cavalcade, and the purpose is the public could watch the buffalo to be slaughtered and the head will be floated on the sea. Meanwhile, the meats will be distributed to local people. Before that, the buffalo head is purified with prayer by the local cleric [3].

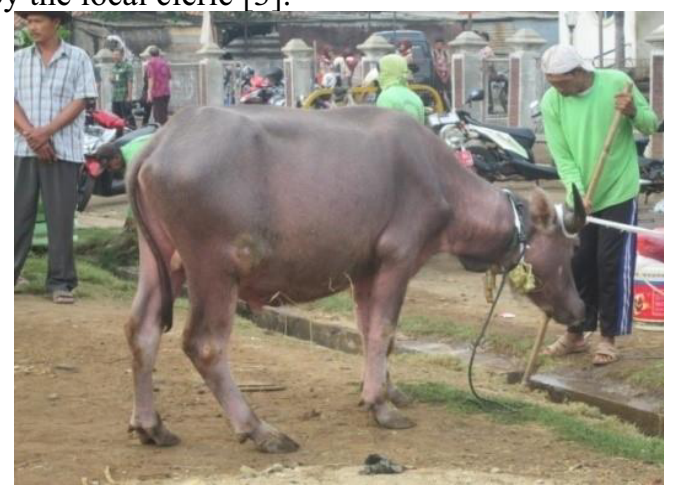

Fig 1. The buffalo that will be slaughtered, the head will be thrown into sea for Sedekah Laut.

(Source: Documentation of Buku Kuliner Tradisi 2016) 
Secondly is selamatan and pilgrimage to Cik Lanang tomb, in Kartini Beach, at the time of Asar ba'da, after Magrib and continued with selamatan and pilgrimage to Kyai Ronggomulyo tomb, one of Pangeran Diponegoro soldier who has survived to the Jepara, and opened Ujung Batu villages. Therefore, until now Kyai Ronggomulyo tomb is still respected and becomes local pilgrimage destinations (Interviewed with $\mathrm{Mrs} \mathrm{Hj}$. Iskarimah, July 12, 2016). Followed by wayang kulit performance in TPI Ujung Batu by taking on the play Raden Gathutkaca Winisudho.

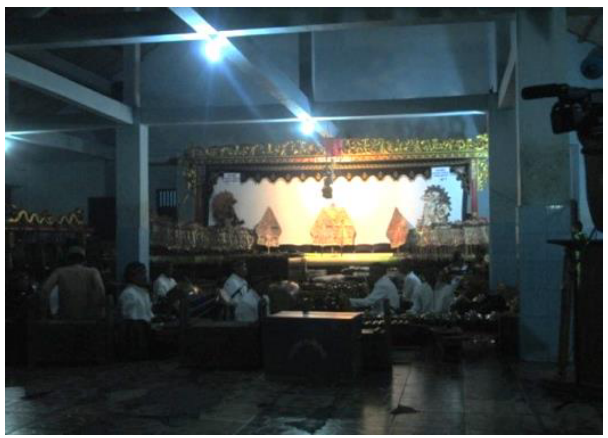

Fig 2. Wayang Kulit performance all night long.

(Source: Documentation of Buku Kuliner Tradisi 2016)

Pelarungan sesaji is carried out by 2 (two) ships that Dinas Pariwisata Jepara has prepared. One ship is used to carry placement and guests, and another ship forms a miniature replica of the ship used to transport sesaji. Pelarungan sesaji followed by multiple fisherman ships, which later after the pelarungan finished will enliven the competition party (Lomban) as Sedekah Laut tradition ceremony climax. It is not known when the competition was held for the first time. However, in 1882, there was a cultural festival called ba'da Lomban. Local communities, regents, and village heads play a role in the preparation of the competitions. Market activities in the city of Jepara closed and joined in this contest party. Lomban implementation takes place every year. In 1999, visitors enlivened the Lomban party as many as 26,158 people. The Lomban party has originally belonged to the fishing community into the property of the Jepara community in general. Sedekah Laut ceremony creates public interest and becomes a tourist attraction in Jepara [4,5].

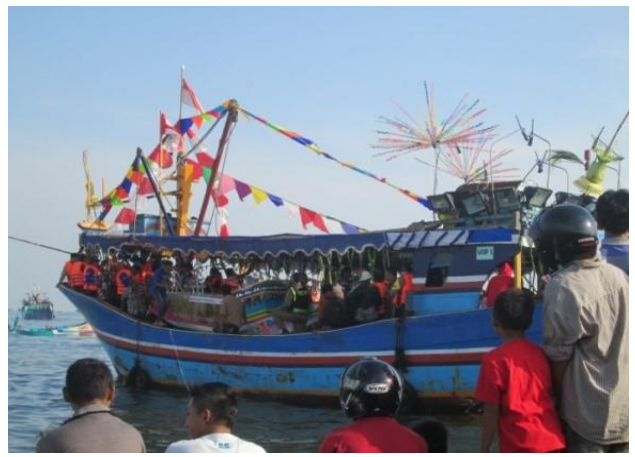

Fig 3. Sesaji ships (miniature) brought ships to pelarungan place.

(Source: Documentation of Buku Kuliner Tradisi 2016) 


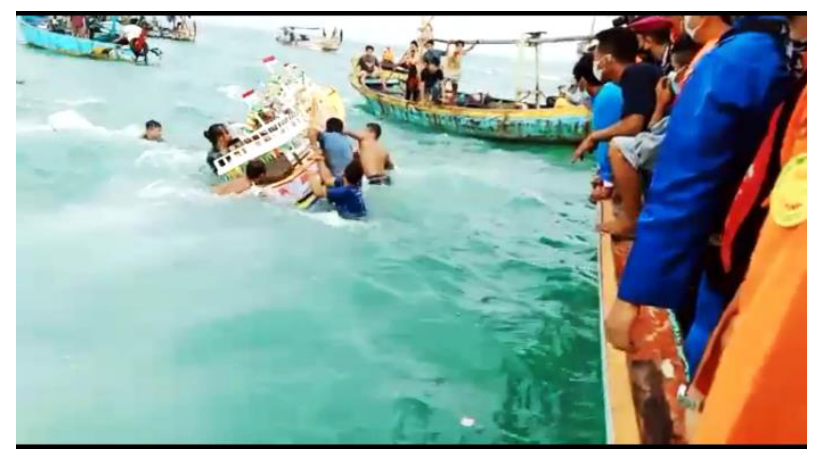

Fig 4. Sesaji ships thrown to the sea and up for grabs by pelarungan participations.

(Source: Documentation of Sultan Muhammad Aqidallah, 2021)

Continuity and preservation of this tradition can be seen from the hopes and prayers carried out in the ceremonial procession, especially in the inherent meanings and definitions of sesaji or foods. Several types of sesaji and foods give the meaning of goodness and blessings in Sedekah Laut, such as buffalo head, dhekem chicken, bucek, nasi nuk-nukan sayur kunci daun kelor, abang putih porridge, and sawan laut.

Head buffalo has been slaughtered and wrapped with mori fabric and have been given prayer by Kyai, and then becomes as sesaji for dhanyang, the master of Laut Jawa. Buffalo head election for sesaji because buffalo are animals that like in cold places, even if in hot places usually not for long times. The meaning of buffalo head for sesaji is that there is always a harmonious atmosphere in social life and avoiding a hostile atmosphere, which tends to create hostility.

Dhekem chicken is Jepara's local name to mention ingkung, which cooked a whole chicken with no cut. For Jawa people, ingkung means "enggala jungkung", which means "to sujud immediately, " which is prayer for Allah. Jawa people has another meaning that ingkung and "enggalo manekung" are dhikr for Allah. Therefore, ingkung for Jawa people is asking to pray for Allah immediately by prayer and dhikr.

Bucek is mini tumpeng. Called yellow bucek, because that mini tumpeng is made of yellow rice. The yellow colour in the Jawa people is gold, so that yellow bucek can be interpreted as the lucky symbol and prosper. At the end of tumpeng, pinned shallots, trasi, and Lombok. All three ingredients believed that able avoid bad things. There is also side dish on yellow bucek like egg, local chicken and urap with 7 (seven) sorts of vegetables, which symbolizes as a hope of help from "invisible power" and availability "power" to avoid the dangerous things (Interviewed with Mrs Hj. Iskarimah, July 12, 2016).

White Bucek is similar to yellow bucek; the difference is just the colours. However, the meanings to be different. Tumpeng made with white rice symbolizes holiness, so it is often used to complement religious ceremonies (Interviewed with Mrs Irma Wulandriani, October 10, 2017).

Nasi nuk-nukan is printed white rice by the bowl. There are five of them. According to the Jawa people, odd numbers had special powers.

Sayur kunci godhong kelor (Moringa oleifera) is Cik Lanang favorite who inhabit Kelor Island. This island changed to Kartini Beach. In Jawa people religious, kelor leaves mean plants have magic power and are related to spirits (chase away).

Gesek is Jepara's local term to called salty fish. Therefore, gesek goreng is fried salty fish. Salty fish is one of the production fishermen, and mark that Jepara is one of the places where there are fishermen like Ujungbatu.

Sawan laut is a kind of boreh as medicine for people attacked by black magic or disturbed by sea spirits. The medicine consists of a variety empon-empon and crushed 
flowers with traditional tools. The ingredients sawan laut can be purchased in the traditional market on empon-empon sellers (Interviewed with Mrs Hj. Iskarimah, July 12, 2016).

Jajan Jajan Pasar always is complementary in a traditional ceremony. Jajan pasar means sedekah for a safe life, especially spiritual, inner, or safe from sprits things. On this ritual,jajan pasar consists of kupat, lepet, horog-horog, abang putih porridge, banana, krasikan, krupuk rambak, jipan, and steamed cupcakes.

Abang putih porridge is a porridge made of rice. Abang porridge is made with coconut milk and brown colours Jawa sugar, but Jawa people called bubur abang (red). While the white porridge is made with coconut milk and salt, so the taste is savoury. Composite of red porridge and white porridge makes the taste is legit. The meanings of the porridge, according to Jawa people believed is created human. White porridge means "seed from father" or white colours of sperm symbolize, and red porridge is "red blood" symbol from mother. Both of them are put together on the same container as new human birth. Red-white porridge is usually served for ceremonies, and someone hopes for blessing and salvation. Red-white porridge has courage philosophy (red colour) and sanctity (white colour).

Setangkep banana is two Lirang. Lirang is Jawa local term called one comb banana. Banana for Sedekah Laut is raja banana. Raja banana symbolizes the prayer to become a fair character, noble-minded person, and keep the promises. Using banana as ubarampe sesaji means with ethics, so that ritual participation can live a life like banana character, living everywhere and adapting to the environments. In Jawa people, that definition is ajur ajer [6]. Every part of banana-like leaves, flowers, logs, and humps can be utilized for humans.

Various prayers and hopes are served and delivered to Allah SWT by many kinds of sesaji or foods. Starting from the desire for a peaceful life with no dangerous things, harmonies life, always prayer with their religion (especially Islam), and hopes for a happy and successful life (especially fishermen as the leading proponent of Sedekah Laut).

For people with various livelihoods, such as closing ceremonial Eid ul- Fitr, with foods like kupat, lepet, and opor ayam (Interviewed with Endah Wahyuningsih, May 20, 2021). The mandatory dishes are intended to build intimacy between families and communities like ketan as based for lepet. Even though the pandemic is not over yet, pelarungan and a series of ceremonies are still carried out, although it must comply with health protocol.

\subsection{Procession, Meaning, and Tenjin Matsuri Japan Ceremony Continuity}

Tenjin Tenjin Matsuri is a traditional ceremony in Japan that aims to celebrate and make offerings to gods. Tenjin matsuri comes from the word Tenjin which means kami (God), and matsuri means festival or celebration. This ceremony takes place once a year at Tenmagu Shrine, Osaka. Tenjin Matsuri in Japan held for 2 (two) days, on July 24th and 25th. Tenjin Matsuri purposed to pray for gratitude and get closer to kami (gods) for the blessings received. The Tenjin Matsuri celebration begins with a mikoshi parade performed by 80 local women in the Tenjinbashisuji shopping area as a form of welcoming the Tenjin Matsuri festival [7].

On 24th or Yoimiya is the opening part of the festivals. This opening was held in some event rundown, such as drum sounds (moyoshi-daiko) at 4 mornings. Moreover, the next event is Shinto rituals like performing various offerings, prayers, or called HookonagashiShinji. The ritual for God which to let a God's sword (kamihoko) made by white-wooden stick flow on the Dojima river near the shrine. The purpose is purification which removes defilement and bad things that affects society symbolically in the river. However, this procession is not open to the public. People still can watch the festivals like Moyoshidaiko, shishi-mai (lion dance), danjiri-bayashi (festival music all day long), yotsudakeodori (four-bamboo dance), ryu odori (dragon dance), mikoshi. Aboshi Tsuyoshi revealed 
that music contributed to the Tenjin Matsuri ceremony. The main music at this festival is moyoshi-daiko and danjiri-bayashi. The music was an accompaniment in the continuation of the traditional ceremony and has meaning in history, performance structure, musical technique, and characteristics of folk songs [8].

The festivals are held every year and served foods for ceremonies consist of water, sake, salt, mochi, red sea bream, seaweed, daikon radish, burdock, taro, lotus root, gourds, cucumbers, apples, and the hoko [9]. Food in the rituals has meanings. Mochi boiled at a high temperature, so it lasted longer in the Japanese summer. Traditional Tenjin bento filled with boiled rice (shiramushi) and pickled plums, wrapped in bamboo bark. The root vegetables give energy, and cucumbers give refreshing for the body.

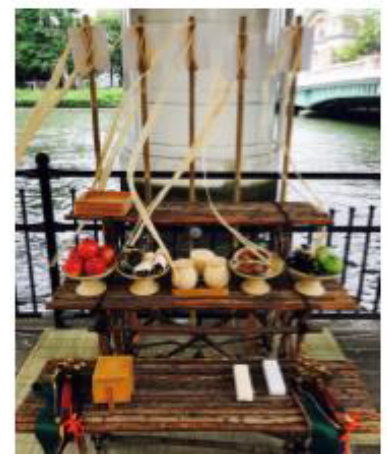

Fig 5. Offerings or Hoko Nagashi Shinji

(Source: Documentation of Uchimashô - Fieldnotes on Tenjin Matsuri)

At $25^{\text {th }}$ or Honmiya is ceremonies held by two rituals, such as Riku Togyo (land crossing) and when the night is Funa Togyo (crossing by ships). The ceremony started with participant performances in the shrine with formal greetings. There have 2.600 participants in this ceremony. Moyoshi daiko came in around 3 p.m and performances in front of kami with other participants. Riku Togyo followed with Funa Togyo, which is the peak of the ceremonies. The process is held around 6 p.m when mikoshi accompanying tools and boxes of provisions are transferred onto boats. The procession opened to the public, not only the processions, many appearances performed on the street.

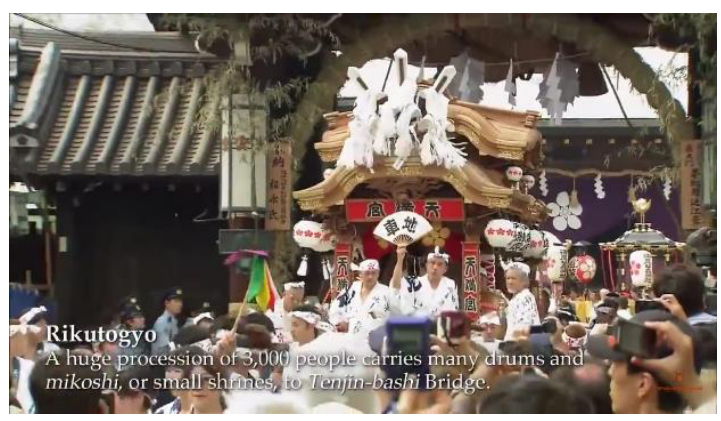

Fig 6. Riku Togyo

(Source: Welcome Kansai/ Youtube.com)

Tenjin Matsuri has become one of the biggest festivals in Japan. The implementation matsuri means in various ways. According to Shinto, a matsuri is a form of gratitude to kami for blessings received. And then, a matsuri is a prayer to kami that it has given 
convenient life. Another meaning of matsuri is for entertainment. As previously described, matsuri also means local festivals. The event was enlivened by a group of spectators who saw the beauty of matsuri implementation and ritual elements.

\subsection{Concept of Water and Cultures}

Sedekah Laut Jepara ceremony and Tenjin Matsuri are both use water as a medium in ceremonies. Continuity of Sedekah Laut means blessings to nature (sea) through ceremonies. What is given by nature will be returned to nature, one of which is through a Sedekah Laut ceremony. The Japanese also implement this. Japanese people appreciate nature, like mountains, rivers, trees, and streets. The people considered nature a holy thing and should be appreciated [10] Japanese belief in Shinto. Shinto is a belief in kami (gods) who has power for the universe. Matsuri can also be interpreted as Japanese local festivals with ceremonies and purification ourselves, giving an offering to kami, prayer, express gratitude, and blessings, etc. [11]. A Shinto believer permanently preserves nature and is scared of kami if they are not taken care of it or damage the environment. To express gratitude for the blessings, Shinto believers do ceremonies or matsuri.

Sedekah Laut ceremony and Tenjin Matsuri use water in ritual has become a culture that continues to be preserved even in the middle of modern society. Culture is minded or common sense. The ceremonies of Sedekah Laut and Tenjin Matsuri show the concept of a culture where humans must preserve nature and not destroy it. That concept is held in ceremonies with an event rundown involving a group of people. By carrying out the ceremony, humans indirectly have cleaned nature from the dirt that may damage it.

\section{Conclusion}

Pandemic in these days gives impacts in many sectors. Implementation of all activities must adhere to health protocols, like physical distancing, wearing a mask and changing it every 4 hours, avoiding touching, washing hands frequently using soap, etc.; appeals continue to be made to reduce transmission COVID-19. Sedekah Laut ceremony and Tenjin Matsuri involve many people who have become impacted by COVID-19. These days (2021), the implementations of Sedekah Laut done not as usual. Local people cannot watch the ceremonies like before even though the ceremonies did not decrease the meanings. People got meanings in spiritual, work motivations, and beliefs. Sedekah Laut and Tenjin Matsuri ceremonies show the cultural concept that humans must protect and preserve nature and not destroy it. Water is one of the mitigation measures for COVID-19 through community traditions so that prevention of COVID-19 can be also be done through ceremonies. 


\section{References}

1. M. Aqil, Y. Atsushi, A. Prabowo, Model Pengelolaan Sumberdaya Air di Jepang, INOVASI, 4 (2005).

2. G. Jaeger, and P. Selznick, "A Normative Theory of Culture", American Sociological Review, 29, No. 5 (1964).

3. Sri Indrahti, Siti Maziyah, Alamsyah, Yanuar Yoga P, Kuliner Tradisi: Simbol Komunikasi Budaya Masyarakat dan Alam di Jepara (2019).

4. Alamsyah, "Budaya Syawalan atau Lomban di Jepara: Studi Komparasi Abad Ke-19 dan Tahun 2013", Humanika, 18, No. 2 (2013).

5. Sri Indrahti, "Syair Doa Keselamatan dalam Sedekah Laut Jepara di Masa Pandemi", Endogami: Jurnal Ilmiah Kajian Antropologi, 4 (2021).

6. M. Solikhin, Ritual dan Tradisi Islam Jawa, Narasi (2010).

7. Soraya Khairuna Naibaho, Kearifan Lokal dalam Perayaan Tenjin di Osaka (Osaka de Okunau Tenjin Matsuri Jimoto no Chie), Universitas Sumatera Utara (2021).

8. Aboshi Tsuyoshi, "The music of Osaka's Tenjin Festival”, The Society for the Research of Asiatic Music, 51 (1987).

9. Carmen Săpunaru Tămaș, "Uchimashô - Fieldnotes on Tenjin Matsuri”, IDB SCIPIO, 17 (2018).

10. Yusuke Shindo, Mengenal Jepang, Kompas (2015).

11. Herniwati, "Masyarakat Jepang Memaknai Matsuri dalam Kehidupannya", SOSIETAS, $1(2011)$. 